\title{
Pyrrhic Victories for the Friends of Whales
}

THE annual meeting of the International Whaling Commission ended last week with Professor J. L. McHugh (its chairman) in high spirits, its opponents (the environmental lobby) in high dudgeon and its business (the whaling industry) still very much a going concern.

At the end of the commission's four day session, at which the plan for a total moratorium sank without trace, McHugh described the meeting as "perhaps the most successful the commission has ever had". Declaring that "this has finally got the whaling commission where it ought to be", he listed as the meeting's achievements

a complete and indefinite ban on the taking of blue, right, gray, bowhead and humpback whales;

- the introduction of international observers on all whaling ships;

- the abolition of the blue whale unit;

- the reduction of quotas on endangered species, and the introduction of one for the minkie whale;

- the creation of a committee to examine IWC's procedures and to strengthen them.

How well is Professor McHugh's enthusiasm justified? The hoped-for 10 year moratorium-supported as it was by a motion at Stockholm that was carried by an overwhelming majoritywent down six votes to four, with four abstentions. The abstentions included Canada, France and Denmark, who voted for the moratorium in Stockholm.

The total ban on bowhead, right and gray whales was introduced more than twenty-five years ago, and blues and humpbacks have been protected since 1967 and 1966 respectively. What this meeting of the IWC has done is to extend the protection indefinitely, instead of for renewable periods of between three and five years.

The International Observer Scheme was first mooted in 1955, but even now it is not truly international ; the larger whaling nations simply exchanging observers.

The blue whale unit, now finally abolished, has been the IWC's biggest curse. It equates 1 blue whale to 2 fin whales to 2.5 humpback whales to 6 sei whales, and catches in the Antarctic have been estimated in these units. As a result, the larger whales are hunted to near extinction before the smaller whales are sought, as about the same amount of effort goes into catching a sei whale as a blue. The abolition of this arithmetic was first suggested in 1954 , and has been abandoned only now that the blue and humpback whales have to be completely protected and when fins are heavily depleted.

The reduction of quotas, giving the numbers in Table 1 , is a move in the right direction, but the new quotas are a mere 2,500 or so below the actual catch for last year. And the simple figures hide certain facts. The fin whale is heavily depleted, and for stocks to reach maximum sustainable yield (MSY)--the level at which the maximum number can be taken every year in perpetuum-it has been estimated that a complete moratorium on the species would be needed for 25 years. At the level of hunting now proposed, about 60 years would be needed for stocks to reach the MSY. Again, the quotas restrict catches only

Whale Quotas for 1972-73

\begin{tabular}{|c|c|c|c|c|}
\hline Area & Species & Quota & 1971 catch $^{1}$ & 1971 quota \\
\hline Antarctic & $\begin{array}{l}\text { Fin } \\
\text { Sei } \\
\text { Minkie }\end{array}$ & $\begin{array}{l}1,950 \\
5,000 \\
5,000\end{array}$ & $\begin{array}{l}2,683 \\
5,456 \\
3,020 \dagger\end{array}$ & $2,300 \mathrm{BWU}^{*}$ \\
\hline North Pacific & & $\begin{array}{r}650 \\
3,000\end{array}$ & $\begin{array}{r}732 \\
3,463\end{array}$ & $\begin{array}{l}1,046 \\
3,768\end{array}$ \\
\hline & $\begin{array}{l}\text { Sperm (male) } \\
\text { (female) }\end{array}$ & $\begin{array}{l}6,000 \\
4,000\end{array}$ & $7,328+$ & $10,841 \ddagger$ \\
\hline $\begin{array}{l}\text { Southern Hemisphere } \\
\text { Total }\end{array}$ & $\begin{array}{c}\text { Sperm (male) } \\
\text { (female) }\end{array}$ & $\begin{array}{r}8,000 \\
5,000 \\
38,600\end{array}$ & $\begin{array}{c}10,796 \ddagger \S \\
41,000 \text { (approx.) }\end{array}$ & No quota \\
\hline
\end{tabular}

${ }^{1}$ Source: Bureau of International Whaling Statistics, Norway.

* Blue Whale Units.

+ Not included in the Blue Whale Unit.

No separate quotas by sex.

$\$$ Includes Sperm whales caught by non-IWC countries.

Includes all large whales in all areas. Does not include several thousand small whales and more than 250.000 dolphins which are not protected in any way. in certain areas; as many minkie whales as any country wishes can be taken from the North Pacific, for example, and any species not protected or named in the table can be taken at will.

What crumbs of comfort can be picked from the IWC's table? Precious few, but there is some hope for the future. The Japanese and Russians have agreed that quotas should be further reduced next year, and the United States and the USSR agreed to cooperate over whale research. A proposal for an International Whale Decade to enlarge the sketchy knowledge of whale habits was approved in principle. Attempts are to be made to get the non-IWC whaling nations - Peru, Portugal, Spain, Brazil and Chile-who between them account for between 2,000 and 4,000 whales a year, to join the IWC, and the procedure committee is to look at ways of giving the organization some teeth. In the past its bark may not have been particularly strong, but its bite was non-existent.

There is also some comfort in that the quotas now set for sperm, sei and minkie whales are at the theoretical MSY level. But there remains great uncertainty about the accuracy of the calculations. Estimates of whale populations are based on sightings from killer ships which naturally go to the areas where experience has taught them whales are to be found, so their accuracy as total population estimates is questionable. A decade of research on the subject should provide figures from which MSY levels could be set with certainty. Meanwhile the danger is that, while a fishery if overexploited can recover within a few years, whales, with their slow mammalian reproduction cycle, can take decades to recover.

Mr Russell Train, chairman of the United States Council on Environmental Quality and head of the American delegation, said last week that "there's room for improvement but it's not been a bad week". But "we are managing by guess and by God, rather than on the basis of fact".

\section{ROTHSCHILD}

\section{Shot Across the Bows}

THE customer-contractor principle is not necessarily the universal answer to the organization and management of government research and development, 